\title{
Roses: the latest chapter in the conflicted history of controlling irrigation water in the Ecuadorian Andes
}

\author{
Patricio Mena-Vásconez ${ }^{1}$ (D) $\cdot$ Rutgerd Boelens ${ }^{1,2}$ (D) Jeroen $\operatorname{Vos}^{1}$ (D)
}

Received: 29 April 2019 / Accepted: 20 June 2020 / Published online: 7 August 2020

(c) The Author(s) 2020

\begin{abstract}
The history of the Pisque watershed in the Ecuadorian Andes is one of local livelihoods and resources being disrupted by external actors: Incas in Pre-Columbian times, Spaniards during the era of Conquest and Colonisation, and, during the Republic, white-mestizo elites followed by international businesses. Local communities have suffered from, rebelled against, and adapted to adverse, ever-changing socioeconomic, environmental, and political conditions. We trace this history from a political-ecological standpoint, applying the Echelons of Rights Analysis framework and the hydrosocial territory concept to examine conflicts over resources, norms, authorities, and discourses related to irrigation water. The centuries-old saga of battles over water in Pisque helps us understand the latest chapter in the story: the onset of rose agribusinesses, inheritors of the privileges of colonial haciendas. The recent arrival (ca. ten years ago) of small locally managed greenhouses adds complexity to the "food vs. flowers" dichotomy. It also makes it difficult to predict the effects on local attitudes to food security, water justice, and sovereignty.
\end{abstract}

Keywords Water resources · Peasant irrigation · Conflict analysis · Flower agribusiness · Andes · Ecuador · Recursos hídricos · Riego campesino · Análisis de conflictos · Agronegocios de flores $\cdot$ Andes $\cdot$ Ecuador

\section{Resumen}

La cuenca hidrográfica de Pisque, en el norte de los Andes del Ecuador, tiene una larga historia de usurpación de los recursos de los habitantes locales por actores externos: los Incas en la época precolombina, los españoles durante la Conquista y la Colonia, así como las elites blanco-mestizas, y más tarde las empresas internacionales, durante la época republicana. Las comunidades y familias locales han sufrido, se han rebelado y se han adaptado ante unas condiciones socioeconómicas, ambientales y políticas adversas siempre cambiantes. Este artículo examina esta historia desde un punto de vista político-ecológico, aplicando el marco de Análisis de Escalones de Derechos (ERA Echelons of Rights Analysis)

Patricio Mena-Vásconez

pamv@gmail.com

1 Water Resources Management Group, University of Wageningen, P.O. Box 47, 6700 AA Wageningen, The Netherlands

2 Centro de Estudios Y Documentación Latinoamericanos (CEDLA), University of Ámsterdam, Roetersstraat 33, 1018 WB Amsterdam, The Netherlands 
y el concepto de territorio hidrosocial para examinar los conflictos sobre los recursos, las normas, las autoridades y los discursos relacionados con la escasa agua de riego. La centenaria historia de batallas por el agua en el Pisque es el trasfondo y proporciona un contexto a su último capítulo: el reciente inicio de la agroindustria de rosas, heredera de los privilegios de las haciendas coloniales. El auge más reciente (hace unos diez años) de pequeños invernaderos de exportación de rosas administrados localmente agrega complejidad a la dicotomía de "alimentos contra flores" y hace que las perspectivas de la población local de recuperar y retener la seguridad alimentaria la justicia hídrica y la soberanía de gobernanza sean impredecibles.

Palabras clave Recursos hídricos · Riego campesino · Análisis de conflictos · Agronegocios de flores $\cdot$ Andes $\cdot$ Ecuador

\section{Introduction}

Ecuador is a particularly biodiverse country. The Andes, crossing Ecuador from north to south, create a natural ladder of ecosystems and climates, home to an astonishing variety of life between the Galápagos and the Amazon (García et al. 2014). To take one example, Ecuador has been hailed as "the land of orchids", with more than 4000 recorded species (Meisel and Woodward 2005). However, if one asks around the world (and even within the country), "What flower is Ecuador famous for?" most would answer: "Its amazing roses". A Google search on "Ecuador" and "flower" produces results with native and non-native flowers, of which more than half are "export roses". The vast assortment of autochthonous species is being eclipsed by a very non-native arrival. The Andes are the environment where rose agribusiness started to boom three decades ago.

Best-selling Spanish fiction writer Alberto Vázquez-Figueroa (2012) used this fact for his novel Codicia (Greed). One of the characters-a very wealthy Ecuadorian woman living in Spain —asks an acquaintance:

Have you ever gifted someone with those long-stemmed Ecuadorian roses as a gift? Yes, occasionally...

You see, my father was one of the first to cultivate them, given that they grow best in certain conditions of soil, altitude, and weather found only in lands very close to the equator.

The woman got closer to a vase from which she took a perfect flower; after inhaling its fragrance, she went on:

Well, it turns out that my family owns thousands of hectares of that type of land. So, we now export all kinds of flowers throughout the whole year, we manage our own chain of flower shops $[\ldots]$ and we deal with heaps of money ...

This exchange hints at several conditions underpinning the emergence and growth of the export business for fresh-cut roses in the Ecuadorian highlands: an appropriate and distinctive biophysical setting, historically powerful families with vast expanses of suitable land, the concentration and flow of considerable amounts of money, and the existence of an international market for these goods.

However, some other conditions, also vital to develop successful flower farming in the tropical mountains, are not explicitly mentioned: an abundance of water and relatively 
cheap labour, the presence of the necessary infrastructure (irrigation systems, roads, airport), the existence of fiscal incentives typical of a neoliberal globalising economy, and the arrival of external—frequently international—investors (Mena-Vásconez et al. 2016).

The Pisque watershed, around the towns of Tabacundo and Cayambe, and one-hour drive north of the airport of Quito, is the main rose-producing area in the country. Within the context of the rise of rose floriculture in this watershed, this text traces and examines the conflicts around access to and control over irrigation water for local food production. Food sovereignty and water justice have been at the core of the history of a territory that has been subject to centuries of encroachment and subjugation; at the same time, the original dwellers have, on the one hand, fought fiercely to maintain their autonomy, and, on the other hand, struggled to adapt to the ever-changing biophysical, socioeconomic, and political realities of the watershed (Becker and Tutillo 2009; Hidalgo et al. 2017). The central question of this article is: How have socio-environmental conflicts related to irrigation water developed throughout the Pisque basin's history and shaped the social structures of today's flower-dominated hydrosocial territory?

This analysis is relevant beyond just this case study because it illustrates the importance of historic impacts in understanding the conflicts of today's export industry. The Echelons of Rights Analysis (ERA) and hydrosocial territory analytic frameworks highlight the interconnectedness of biophysical, technological, legal-institutional, socio-economic and cultural-political factors in grasping the complexity of water-grabbing and local struggles against it.

After this introduction we establish a conceptual framework outlining the notion of hydrosocial territory and presenting the ERA approach. We use this to examine the past and present interactions between local producers and powerful external actors in disputes over resources, rights, authorities, and discourses. Next, we offer a brief outline of the history of the watershed from pre-Columbian times to the present day, emphasising access to, and control of, water resources. Finally, we analyse the conflicts and draw concluding remarks.

\section{Hydrosocial Territories and the Echelons of Rights Framework: Conceptual notions}

Past and current developments of water governance in Pisque show that water control is the result of deeply contested political processes (Hidalgo 2010; Mena-Vásconez et al. 2017; Roa-García 2014). Water governance reflects socio-economic pressures, local politics, and the power of cultural symbols. These factors steer decisions regarding water control, which manifest themselves in different approaches to the allocation, use, development, and management of water resources (Hoogesteger 2012; Perreault 2014; Zwarteveen and Boelens 2014). In Ecuador and elsewhere, Integrated Water Resources Management (IWRM) policies are founded on inclusive, participatory discourse and liberal premises (where civil society and its governance are portrayed as a set of democratic forces and technological developments that provide ample opportunities for all citizens to fend for their interests). However, the power structures in Pisque demonstrate how different actors have different power to drive water access and control (Yacoub et al. 2015; Manosalvas 2016). Peasant and indigenous smallholders are characteristically excluded from formal governance and, in often racist political practices, they are often deemed "illegitimate" and "unknowledgeable" stakeholders (Boelens et al. 2015). Thus, mainstream water policies planned to involve 
socio-economically marginalised interest groups do not alter the water/power hierarchies and deep-seated inequities, while continuing to produce socio-environmental conflicts, which sometimes surface violently (Boelens et al. 2018).

As stressed by political ecology studies, water governance is about the way nature, technology, and people are intrinsically interrelated and entwined through power structures and societal forces (Boelens 2014; Meehan 2013; Swyngedouw 2009). Here, power relationships shape water flows and vice versa. As has been argued (e.g. Linton and Budds 2014), this becomes manifest in how water is distributed and used in river basins, how and by whom water use systems are designed and managed, how virtual water flows are directed by markets, and how entire hydrological cycles are transformed by human interventions. As a result, it is essential to examine how the interlinked areas of nature, society, and technology are established; by which agents; according to which interests and powers, and with what outcomes. To examine and comprehend these interrelationships, and how they become freighted with meaning within particular boundaries, the notion of "hydrosocial territories" has been proposed (Boelens et al. 2016, p. 2):

$[\mathrm{T}]$ he contested imaginary and socio-environmental materialisation of a spatially bound multi-scalar network in which humans, water flows, ecological relations, hydraulic infrastructure, financial means, legal-administrative arrangements, and cultural institutions and practices are interactively defined, aligned, and mobilised through epistemological belief systems, political hierarchies, and naturalising discourses.

Territories, then, are not naturally or physically confined but dynamically produced by myriad (diverging) actors (Agnew 1994; Elden 2010); hydrosocial territories are shaped, transformed, and (re)produced through the water-connected interactions among society, technology, and nature. Efforts to realise particular hydrosocial territories are intrinsically political constructs - frequently portrayed as objective and neutral entities - that challenge local, alternative views of water and its relationship to the land (a "hydro-territorial ordering"). The disruption of existing local practices of water governance is often the result of hydro-territorial configurations and water management approaches that dislocate local authorities, institutions, water rights, and distribution systems. Thereby, these dominant hydrosocial territories commonly also undermine local notions of socio-environmental justice (Hommes et al. 2016; Hommes and Boelens 2017; Vos and Hinojosa 2016; de Vos et al. 2006).

Rather than constituting passive victims, indigenous families, peasant communities, and grassroots coalitions contest these transformations. By creating alliances, they reshape alternative hydrosocial territories that interact with and challenge dominant territorial orders, thus producing a "territorial pluralism" (McGarry and O'Leary 2014; Hoogesteger et al. 2016). In them, water flows, technologies, resources, rules, and authorities are constantly negotiated, transformed, and contested at multiple scales and in different arenas (Swyngedouw and Boelens 2018; Vos and Hinojosa 2016; Parramond 2016). Day by day, vested powers and dominant socionatural configurations are challenged at different scales (Marks 2018; Borg and Lund 2018), and these may form the basis for the advancement of emergent forms of inclusion and social justice in water governance (Boelens et al. 2014a, b; French 2018; Wilson and Inkster 2018; Hoogesteger and Verzijl 2015). Powerful, vested interests such as those of state institutions, large corporations, and landlords are challenged, forming the basis for a re-negotiation of water allocation and control. These struggles also challenge the legitimacy of formal authorities and dominant discourses and practices (Sanchis-Ibor et al. 2017; Rogers and Crow-Miller 2017). 
In the hydrosocial territory of the Pisque watershed we can clearly see how territorial politics finds expression when diverse actors come into contact with divergent political and territorial interests. Various territorial strategies compete, superimpose, and align to strengthen specific claims on water-control. As a result, actors continuously recompose the territory's hydraulic grid, cultural reference frames, and political-economic relationships (Hommes and Boelens 2018). These clashes are not merely skirmishes over natural resources, but battles over meaning, norms, knowledge, identity, authority, and discourses: the arena for irrigation-related conflicts at the Pisque watershed consists of different layers of issues over which actors struggle. To unravel the specificities of and relationships among these layers we use the Echelons of Rights Analysis (ERA) framework (Boelens 2015; Zwarteveen and Boelens 2014).

The ERA framework holds that water rights, rather than constituting uniform and universal property relationships, are socionatural, cultural-political relationships and expressions of power. ERA considers the enormous variety of existing water rights as dynamically evolving hybrids of plural legal frameworks played out in local water territories (Roth et al. 2015; Jackson 2018). Beyond resource battles, water conflicts are an intrinsic part of struggles over access to and control over water. ERA therefore proposes to examine water conflicts as encompassing the following four connected echelons (Boelens 2009; DuarteAbadía et al. 2015; Stoltenborg and Boelens 2016).

The first echelon relates to the dispute among actors over access to the resources: water itself, its control and use, as well as all the material means to implement water rights. This includes infrastructure, money and labour brought into floriculture businesses. These can be seen as the descendants of powerful interested parties that have long been benefitting from the resource to both the detriment and contestation of local communities and peoples.

At a second level are the conflicts linked to alternative sets of rules related to the acquisition of water rights and the operation and management of an irrigation system; they include roles and responsibilities of users, and how and when water is allocated within a heterogeneous set of values and meanings. They refer to the contents and meaning of "water rights". Pisque is a showcase of legal frameworks (communal, official, entrepreneurial) that interact and collide.

The third echelon refers to the conflicts that arise over the definition and exercise of authority concerning water control. It is common to find multiple sources and forms of authority whose role is formulating and enforcing rules and rights. This introduces the dilemma about who is authorised to impose norms, and to decide and apply sanctions within a system of hierarchies involving class, wealth, gender, ethnicity, and age. Here, the legitimacy of particular positions and forms of authority regarding irrigation water in the watershed is fundamental.

The most abstract level is that of discourses, i.e., the (hegemonic and alternative) regimes of representation that legitimise or contest resource distribution, the contents of rules, and authority. These discourses link and shape the social/technical, human/natural, and scientific/practical water scenarios morally, institutionally, and politically: they defend shaping (or conserving) given hydrosocial territories. As such, they can be understood as truth-constructing manifestations and practices (e.g. Foucault (1995 (1975)) that establish, impose or defend certain schemes of governance, while delegitimising, oppressing or resisting alternative perspectives and accounts of reality. Discourses are practice- and action-oriented, aiming at gaining adherents and demobilising antagonists through inspiring and legitimising activities and campaigns in an evolving process, where the framing of one discourse is more effective if it succeeds in resonating its values with the framings of other stakeholders (Benford and Snow 2000; Bain and Selfa 2013; Hulshof and Vos 


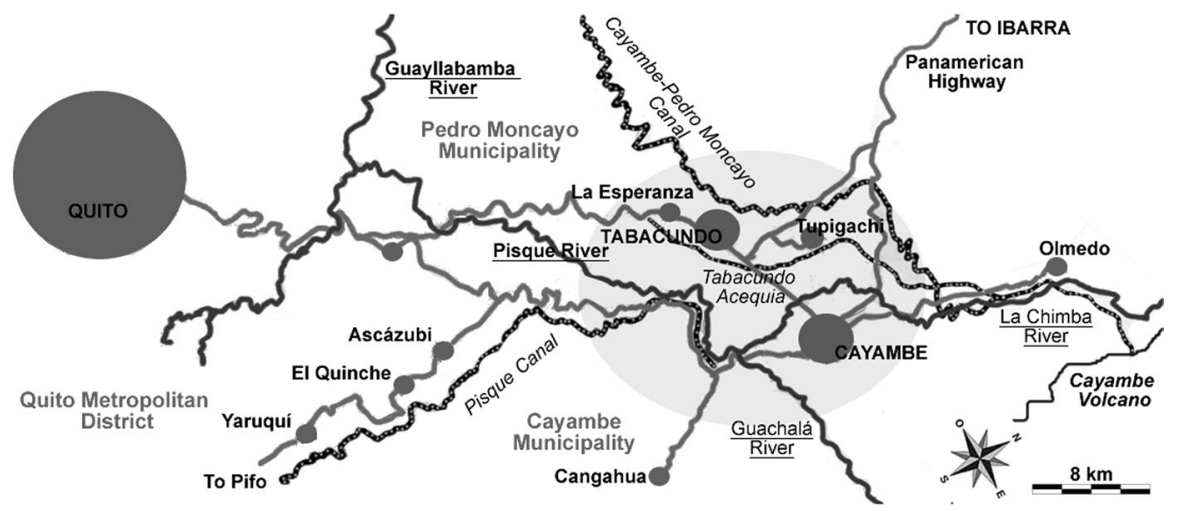

Fig. 1 Study area, approximate location in Ecuador (left) and main features (right)

2016). At the Pisque watershed, the apparently simple original dichotomy of "local versus foreign" developed into a complex mesh of differing perceptions, value systems, and discourses, and consequently diverse, contested, and hybrid hydrosocial territories.

\section{Alien flowers in the Andes: old and new origins}

Flower agribusiness, specifically rose farming, appeared and developed rapidly some 30 years ago in Ecuador's political geography, particularly in the Pisque watershed in the northern highlands some $50 \mathrm{~km}$ to the north of Quito. The factors contributing to this fast rise of the flower business include several socio-economic and political circumstances that began as far back as the Spanish Conquest at the beginning of the sixteenth century.

\section{The Pisque River watershed: from corn to wheat}

Although the region has been inhabited for millennia, we know little about people who lived there first. Prior to the Inca and Spanish invasions varied groups occupied the territory we know as Ecuador. The Pisque region, now comprising basically the Cayambe and Pedro Moncayo cantones $^{1}$ in Pichincha Province, was part of the territory of the Caranqui (Fig. 1). A relatively large indigenous group, they occupied the plateau that runs from the Guayllabamba River (north of Quito) to the Chota and Mira rivers, near the contemporary border with Colombia. This federation, including the Kayambi, tried to assemble itself more strongly to face the Inca invasion (Becker and Tutillo 2009). The Caranqui had come from the north thousands of years before but their diverse languages, unintelligible to one another, have disappeared; there are no written records and their last speakers died in the eighteenth century (Murra 1946).

\footnotetext{
${ }^{1}$ Ecuador is politically and administratively divided into 24 provinces, these into cantones (municipalities) and these into parroquias (non-religious parishes). The Pichincha province is home to the nation's capital, Quito. The study area is located ca. $50 \mathrm{kms}$ to the north of Quito.
} 
Archaeological evidence (e.g. Athens 1980) shows that early Pisque inhabitants were agriculturalists who grew corn, quinoa, potatoes, and beans, and bred guinea pigs and llamas. They applied irrigation via camellones (mounds surrounded by canals). Some of these infrastructures still exist, mainly as part of larger, more modern systems (Zapatta and Mena-Vásconez 2013), which attests to the early and continuous evolution of hydrosocial territories.

This allowed the development of more complex social structures, but there were never large town-like settlements. Families lived scattered across the hilly landscape. A prominent feature were the pyramids and tolas (ceremonial mounds), a manifestation of a complex social, religious, and political organisation (Bray and Echeverría 2014).

The Incas had been in the territory that is now Ecuador for just a few decades when they changed the course of history drastically and ended what Enock called "an unparalleled linguistic and ethnic Babel” (Enoch 1914, cited by Becker and Tutillo 2009). Huayna Cápac, the eleventh Inca emperor, reached what would become the final northern border of the Incan empire shortly before the Spaniards' arrival. The Caranqui joined forces and fought a bloody 17-year war against the Incas. Finally, the Incas triumphed only twenty years prior to the Spaniards' arrival (Costales and Costales 1987).

Some of the Caranqui were taken away as mitmaes - uprooted people taken to far-away places. This was a strategy used by the Incas to subjugate rebel populations, strategically locate friendly populations at the empire's expanding borders and impose the Quechua language over the conquered territories. Correspondingly, many people were displaced to Cayambe from the southern parts of the Inca empire, and probably most indigenous inhabitants nowadays are their descendants (Ramón 1987). The Inca influence on agriculture was different from what happened with Inca religious, cultural, and civil institutions. The short period of Inca occupation did not allow for notable and lasting changes. For example, their famed agricultural terraces never became a prominent infrastructural element of the hydrosocial territory of Pisque (Meyers 1998).

The Europeans arrived in 1534. Sebastián de Benalcázar, Francisco Pizarro’s lieutenant, founded Quito and advanced northwards conquering the lands along the way. The Caranqui became part of the Otavalo corregimiento of the Quito Royal Audience, within the Lima Viceroyalty. For a hundred years (1450-1550) the inhabitants of the region suffered a severe and far-reaching loss of independence, the consequences of which are still felt today and have had a profound relationship with the new agribusinesses; this deeply influenced the conformation of historical and contemporary agricultural practices and power relations in the hydrosocial territory.

Frank Salomon (1980) cites an anonymous account of 1573 that gives us a glimpse of how the Europeans found the lands around Quito:

The natives lived in localities one distant from the next one ... the chiefs and Indians obeyed their cacique [chieftain], who, when he wanted some farming to be done or to get some wood from the hill or make a house, sent a crier who loudly declared his will, and this was understood by the captains, who usually had houses near the cacique, where they resided or had people who warned them of what was needed, then sent their cachas, meaning messengers, and then the people gathered to fulfil the will of the lord.

The Spaniards quickly subjugated the same people that had fiercely resisted the Inca incursions. There are several explanations for this. First, the population must have been tired of the long war that annihilated many people and destroyed their cohesion as a functioning society. Moreover, a good portion of the population was made up of mitmae immigrants 
who most likely had only weak connections to the area. Second, there were horses, firearms, and the unforeseen assistance of alien contagious diseases, the latter afflicting their immunologically helpless victims even before the arrival of the invading armies. Spaniards took advantage of the progress the Incas had achieved in subjugating these peoples and, for example, imposed Quechua as a lingua franca more successfully than the Incas themselves. ${ }^{2}$

At the beginning, local leaders were normally quite willing to collaborate. Local people even joined armies that subjugated other indigenous groups. Gradually more "whites" started to settle in Catholic monasteries and increasingly Spanish-styled towns and estates. The political economy of the hydrosocial territory changed dramatically. Spaniards introduced wheat, barley, and farm animals (cows, horses, donkeys, sheep, pigs). A Castellantype feudal system was established, with indigenous people forced, in serf-like fashion, to perform predominantly agricultural, mining, and textile tasks, often in inhuman conditions. All the rights they had on land and water were grabbed and encroached upon. Among other things, they had to surrender the old irrigation systems that characterised the existing hydrosocial territories and build and maintain new ones that gave water to the new landowners. These systems are a crucial part of the later chapters of the Pisque story (Terán 1994).

The history of this era is not only one of subjugation and suffering, but also of resistance and mobilisation. A veiled yet powerful version of this came within the religious context. Spaniards tried to force Catholicism on their subjects, and on the surface appeared to succeed. However, the Christian elements were no more than skin deep, allowing a system of old beliefs to be maintained underneath. Many indigenous festivities related to the Sun and the arrival of the rainy period, for example, were fused with their most similar European counterparts. A different type of resistance was that of the rebellions against local, and sometimes wider-ranging, oppressors. They included acts of personal resistance such as suicide, destruction of tools, and "laziness"-what Scott (1985) called everyday forms of peasant resistance-but also large uprisings against institutions related fundamentally to the haciendas.

Haciendas became institutions that embodied the zeitgeist of those years. Managed by religious communities or "white" families, they encompassed immense expanses of agricultural and natural lands where indigenous people were assets. They had to work without salary, forced to pay taxes and tithes for catechisation and for land and goods that barely allowed survival (Scott 1985; Larraín 1980). Most of these estates endured the peasant and indigenous mobilisations and subsequent reforms and entered the Republican era; some can still be seen in the present hydrosocial territory as one of the most durable and anachronistic manifestations of past inequities. Indeed, many of the new large flower farms were established on the remaining haciendas and their water concessions, and on the best lands of the Pisque watershed.

\footnotetext{
2 The Kayambi seem to have spoken a "commercial" Quechua at the time of Huayna Cápac's invasion. The Spaniards found it easier to impose the language of the Incas (at least during the first period) instead of teaching Spanish to the conquered populations. Missionaries judged that evangelization tasks could be achieved more rapidly using native languages (see e.g. Aspiazu 2014).
} 


\section{The Pisque watershed: from wheat to cows}

The transition to the Republican era in the decade 1820-1830 did not entail a deep change in the dominance of the haciendas. The colonial era had installed the huasipungo. This Quechua word (meaning "house gate") refers to the system of precarious agricultural work imposed by the Spanish in the Andean highlands. This exploitative relationship was maintained by the landlords throughout the Colonia (commonly considered from the foundation of the city of Quito in 1534 until the end of the colonial period in 1809), and much of the Republican period. In physical terms, a huasipungo was a small portion of land that the owner of the hacienda granted a peasant family in exchange for labour. Usually, the huasipungo sat on poor, usually rainfed soils located in the heights, where families lived in shacks (chozas). The hydrosocial territory was clearly divided in physical and demographic terms between the hacendados on the lower, flatter, irrigated portions, and the oppressed indigenous populace in the upper, rougher, rainfed lands.

In exchange for permission to cultivate and get at best a meagre additional income, the family laboured in the hacienda. They were subjected to concertaje, a bond by which indigenous persons were forced to perform agricultural work over their whole lifetime, passing on the same bonded relationship to the next generation. In the best case they received a minimal wage, and often no wage at all. They were forced to work several days a week on the land and irrigation canals of their master in exchange for the use of a small ragged plot (where they barely managed to cultivate Andean crops). This was usually accompanied by the permission to collect firewood and graze their few cattle on the least productive lands. Water came from rain or the irrigation canals that had been built by the indigenous population previously or as part of the hacienda tasks, i.e. almost exclusively for the owner's use. Huasipungueros were always available and, in addition to their agricultural work, delivered services such as taking care of children, house and pets, etc. The huasipungo originated in the beginnings of the Spanish conquest. The new aristocracy of the wealthy Creole consolidated the system and their descendants continued it for about four hundred years, even after attaining independence from Spain (Borja 2012).

Taken from Jorge Icaza's (1950) piercing indigenist novel Huasipungo, two paragraphs help understand the lot of the local population in these years, especially in relation to irrigation water:

The alleyway is tattooed by an earthen canal of turbid water, where cattle of the huasipungos finds troughs, where pigs make their beds of mud to wallow their ardour, where children, on all fours, quench their thirst [...].

In the gorge of the mountain he could make a hundred Indians who, led by the mayordomo, surely go to the minga [community work] at the ravine. Every month, the same story: water gets stuck up there and it is necessary to clean the channel so that the flow does not decrease and, above all, so that it does not stagnate. In winter, the strong thaws and storms of the peaks unfasten obstacles and dams, releasing the waters that, when rushing into the valley, devastate the animals and the huasipungos on the banks.

Andean haciendas maintained a local level of influence while the Pacific coastal areas had a different form of hydrosocial development. There, agricultural progress came within an international context driven by the successive booms of cacao and bananas 
(there too, based on the exploitation of local and immigrant labour force). The construction of the railroad meant, among other things, a higher integration of the regions. Some produce of the haciendas could reach Guayaquil and other large coastal cities. This augmented the integration of Andean goods into the national market.

The 1895 Liberal Revolution entailed several changes such as the abolition of concertaje and the expropriation of haciendas that belonged to the Church. The 1908 liberal Law of Beneficence or "Dead hands law"-Manos muertas, untouchable lands and waters that belonged to God, administered by the Church and protected by the Spanish Monarchy-confiscated hacienda land and water from the ecclesiastical communities and transferred them to social-service State institutions (Borja 2012). Again, no fundamental changes in the situation of inequity were felt by the oppressed rural population, especially in relation to the profoundly unbalanced land ownership that the conservative-theocratic regime and its feudal economic order had established. The traditional hacienda, now in governmental and private hands, incorporated itself gradually into the national market. More intensive techniques and the greater restriction to access to land and water for local peasant populations meant an extension of cultivated lands (Albornoz 2014).

The introduction of Holstein Friesian cows in the beginning of the twentieth century entailed a boost for the haciendas. Those with particularly good soils and irrigation saw a new opportunity in milk production and many became dairy farms. For the peasant population, this meant both less availability of jobs and a further confinement to upper, unproductive lands. This, in turn, prompted men to migrate to urban centres to get employment as low-paid construction workers and women as generally exploited housemaids.

It is only in the 1960s that developments came about, spurred on by a series of events such as a nascent indigenous movement, agricultural modernisation by large landowners, and the influence of reforms implemented by the Cuban revolution. This hodgepodge of ingredients already points at the development of agrarian reform plagued by contradiction. Indeed, the 1964 Law of Agrarian Reform aimed to achieve two different goals: to eliminate precarious production systems - granting lands from state-owned haciendas to peasants-and to dismantle an agrarian syndicalism that was in the hands of leftist groups. Far from being a pacifying tool, this law kindled land struggles and, consequently, powerful leftist indigenous organisations were established. Over the years, these two visions of agrarian reform (social justice/modernisation) coexisted and established an uncomfortable relationship (Brassel et al. 2008). The development of productive forces and import substitution lead to a second agrarian reform in 1973, the confiscatory nature of which was feared and contested by landowners who managed to pass a law guaranteeing the security of lands that were efficiently worked. In the words of Jordán (2003:32):

The agrarian transformations of the last decades can be synthesised in two major processes: the displacement of the production axis towards agroindustry and export, and social heterogeneity and occupational diversification that currently characterise the rural and agrarian universe. Such processes have had a heterogeneous character, in some cases, they have maintained the features of inefficiency and have configured the presence of a rentier-type business, and in others, have led to the emergence of a modern business, particularly linked to non-traditional export processes.

The Pisque hydrosocial territory was an integral part of this chronicle. Some large haciendas, such as the remarkably vast Guachalá (nowadays partly dedicated to floriculture) covered most of the watershed. The production of Andean crops such as maize, potatoes, quinoa, and local tubers had been done mainly for domestic and local consumption within 
increasing areas dedicated to wheat, barley and later dairy cow pastures, all destined for local and regional markets.

The region is famous for the indigenous leaders that piloted local revolts, becoming symbols of the continuous rebellious nature of the region's inhabitants. Figures such as Dolores Cacuango, Tránsito Amaguaña, and Segundo Gualavisí have become legends and are milestones within the path to the agrarian reforms of the 1960s and 1970s. Through mainly peaceful mobilisations and marches, which earned them imprisonment and abuses, they were able to, among other things, underpin their status as citizens, achieve bilingual (Quichua) education, and pave the way towards powerful indigenous organisations (Becker and Tutillo 2009). Again, these reforms did little to achieve the goal of changing the precarious livelihoods of the peasant population. Nevertheless, some local communities did enter the dairy boom and today manage well-functioning cooperatives.

\section{The Pisque watershed: from wheat and cows to roses}

Ecuador's industrial floriculture was launched during the country's neoliberal turn between 1978 and 1980 (Gaybor 2011; Guerra 2012). In the agitated history of the last 30 years, neoliberal ideas have solidified "the Ecuadorian way". Hence, the origin and development of fresh cut-flower agribusinesses in Ecuador came about within a political and economic environment that included a significant promotion of "non-traditional" agricultural exports that involved not only roses and other flowers but also shrimp and broccoli (Acción Ecológica 2000; Breilh 2007). As in other Latin American countries, neoliberal policies proposed a free (unregulated) market that would not only function well but also form a desirable way to generate economic development and institutional balance.

The Ecuadorian flower agribusinesses started within this neoliberal environment. There was only one way the "free market" flower dream could come true, i.e. through strong State support and not because of State-withdrawal or any "invisible hand". This demonstrated Polanyi's (1944) early perspectives in his work The Great Transformation and is even true to neoliberal godfather Friedrich Hayek's (1944) Road to Serfdom. From the early 1980s, in Pisque the Ecuadorian state had been actively devoted to creating what David Harvey (2015) examined as an "appropriate institutional framework" for securing private property rights and guaranteeing the functioning of agribusinesses and markets. Some thirty years ago a few international entrepreneurs saw this welcoming environment as an opportunity, offering to construct the biophysical, socioeconomic, and political hydrosocial territory they envisaged. International investors and landowners noticed the exceptional biophysical niche, abundant, relatively cheap labour, and market-oriented government regulations referred to at the start of this article. They established rose farms on the remaining hacienda lands, focussed on export markets (Korovkin and San Miguel-Valderrama 2007; Hidalgo 2015). Relatively good roads and the nearby airport enabled flower transport (Guerra 2012). Favourable fiscal and market conditions enhanced competitiveness bolstered by foreign investment (Acción Ecológica 2000; Sawers 2005; Sopper 2013). These zones lie close to the equatorial line and benefit from several comparative advantages: constant daylength and high exposure to the sun's rays; cool springtime-like temperatures in mountainous areas; low labour costs, and proximity to international airports. In all of them, communities and flower agribusinesses share the limited irrigation water, often with conflicts.

With ups and downs, flower agribusinesses have succeeded and even become one of Ecuador's main exports after petroleum. From fewer than a dozen enterprises at the start, in 2014 Ecuador was the world's third-largest flower exporter, after the Netherlands and 
Colombia (UN Comtrade 2015). Volumes rose from ca. 8,000 tons in 1990 to ca. 139,000 tons in 2014, increasing from $0.5 \%$ to $4 \%$ of Ecuador's total exports (from 14 to 798 million \$US). The Pisque watershed has most of Ecuador's large ( $>2$ ha) flower companies, some 150 producing for export. They average 11 hectares with some highly technologically advanced greenhouses. The sector employs some 48,000 direct and 55,000 indirect workers (Guerra 2012; UN Comtrade 2015).

Less than a decade ago, local families ventured into setting up their own small flower greenhouses based on their experience as workers in large businesses and pressed by dwindling incomes from existing agricultural work. In 2015 some 300 small ( $<2$ ha) greenhouses had been established by smallholders, in many cases taking advantage of their previous relations with the big flower farms (experience gained, facilitation of some materials and market-related contacts, etc.) and the possibility to obtain credit, both private- and State-backed. Against all odds, some local floriculturalists have been able to establish very risky yet successful businesses within the flower market chain. The problems they have had to face include conflicts with their own neighbours and communities related to a supposed overuse of irrigation water by the new small rose greenhouses compared to their previous use for cattle and/or traditional crops (Mena-Vásconez et al. 2017).

Even if acknowledging that flowers have provided jobs and prevented emigration, local people are alarmed about the impact on water security and food sovereignty by a non-edible, individually produced commodity that has a high-water demand (Sopper 2013). They also encounter severe problems of pollution, health, and sociocultural conflicts. Flower firms reply that they have modernised the regions where they thrive and have improved local purchasing power, and that they abide by governmental, national, and international socio-environmental standards (Zapatta and Mena-Vásconez 2013). The recent boom of small, locally run farms some ten years ago adds a new complication to an already discordant situation: an export commodity that many communities first rejected and have now started to produce themselves. However, it shares many features with the previous chapters in a continuing history of contested, ever-changing configurations of the hydrosocial territory, driven by struggles over resources, rules, authorities, and discourses.

\section{Examining the water conflicts}

In this section we focus on the conflict over water in the Pisque watershed during the past decades as a result of centuries-old historical events. The hydrosocial territory of the Pisque watershed has been imagined very distinctly by different stakeholders. Dominant stakeholders have imposed their discourses, authority, rules, and water distribution practices and thus shaped the materialisation of the hydrosocial territory in a way that concentrated water and land in the hands of a few families and businesses. However, the indigenous communities also maintained and furthered their visions of the Pisque watershed and struggled to gain increased access to land and water. The four echelons of the ERA framework are applied below to analyse the struggle over the hydrosocial territory in the Pisque watershed.

\section{Conflicts over resources: the first echelon}

Irrigation water comes from the high-Andean ecosystems called páramos (Mena-Vásconez et al. 2011). Their special climatic and pedo-ecological features allow the accumulation 
and gradual delivery of water that comes from rain and the thawing of glaciers. This water collects in particular organo-volcanic soils that suck and release it like a sponge. These seemingly unproductive, but extremely important landscapes have been part of indigenous hydrosocial territories since the first human settlements of the Andes. First used mainly as strategic lookouts, connection paths, ritual locations, bordering agricultural lands, and raw material supplies, they became eventually part of the colonial haciendas. They were mainly used to maintain sheep and constituted the agricultural land that was given back to the indigenous population after the agrarian reforms. Nowadays, specifically at the Pisque River watershed but within broader conflicts, páramo lands are part of a struggle over the configuration of the valley's complex hydrosocial territory, since their water is craved by the large city of Quito, and more locally by large farms (including floriculture) and small landowners (including those who now produce flowers) (Manosalvas 2016).

Water flowing down from the highlands has been used directly from the streams or directed towards irrigation systems, some of which have existed for centuries (Zapatta and Mena 2013). The haciendas and later the Republican State assumed control of all the indigenous canals. In the Pisque watershed two irrigation systems, Pisque and Tabacundo, are important for the flower business. A new canal has been under construction for over a decade. The Tabacundo and Pisque irrigation systems were constructed by haciendas, with help of forced labour by the indigenous communities. The new irrigation system is being constructed by the government.

The Pisque watershed has been the stage for many struggles to regain the control of these canals. As a prime example, in February of 2006 ca. 3,000 peasants took over the Tabacundo acequia, one of the vital irrigation systems in the area, at that time managed by the Municipality; campaigners demonstrated against floriculture as it was receiving the greatest allocation of water from those managing the resource (Hidalgo 2010). These mobilisations forced the State to turn over the canal to a new community-based institution (Castillo 2006), a process that will be explained below. Within this new scheme, each community established its own rules, for example, to decide whether to allow floriculture in their territory.

Table 1 shows the considerable imbalance of water use by grower types, in terms of both acreage and flow. It has been estimated that in 2013 smallholders used some $15 \%$ $\left(2 \mathrm{Hm}^{3}\right)$ of the irrigation water, cattle haciendas some $30 \%\left(4 \mathrm{Hm}^{3}\right)$, and flower agribusinesses some $55 \%\left(8 \mathrm{Hm}^{3}\right)$. Smallholder communities receive only $15 \%$, though they have almost $60 \%$ of the irrigated land (Ochoa 2013). The new boom of smallholder flower businesses intensified water conflicts inside already water-deficient communities.

\section{Conflicts over the contents of rules: the second echelon}

The way in which water and its uses have been treated in legal terms has generated ultimately a constitutional article that establishes a priority gradation of water uses.. Below "human consumption" (drinking water) is "irrigation that guarantees food security", followed by "ecological flow" (adequate natural water provision for ecosystems) and "productive activities" (diverse industrial and economic uses). This regulation is at the base of the conflict that exploded after the appearance of the Pisque flower farms. Before the 1980s all the agricultural production was aimed at regional food security. The change to dairy production did not change this since milk and its derived products are also deemed part of the region's food security. However, new legal rules consider not only food security (which might be realised either locally or by non-domestic food products), but also food 


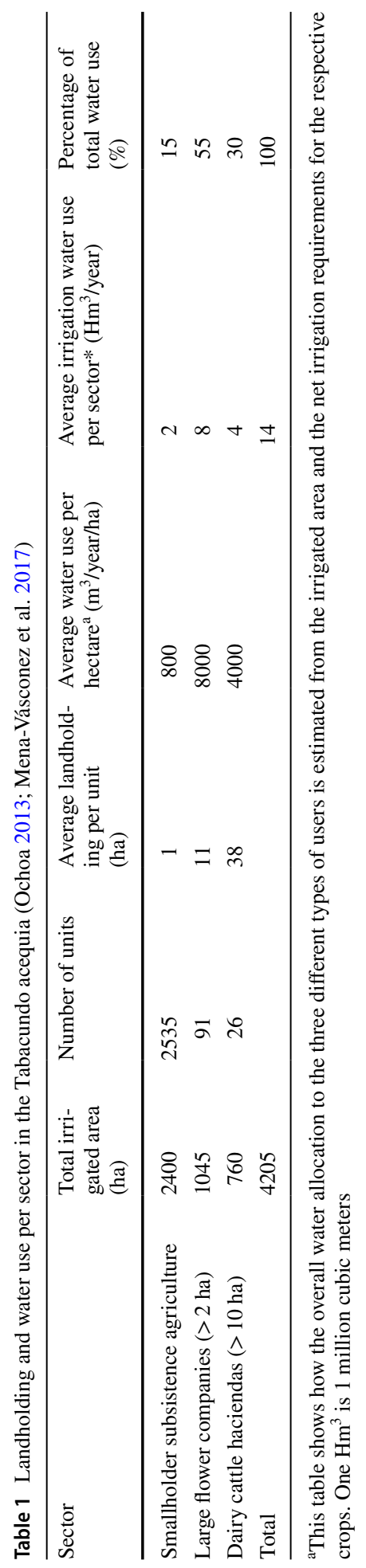


sovereignty: Article 1 of the Food Sovereignty Regime Law declares that the state must "... guarantee persons, communities and peoples the permanent self-sufficiency of healthy, nutritious and culturally appropriate food" (emphasis added). Thus, it is not only a matter of consuming enough food but of doing so in a nutritionally and culturally sound manner and with control over food self-provision (Mena Vásconez et al. 2019).

Flower farms, for the first time in the history of the watershed, started producing a plainly non-edible new item, changing Pisque's socionatural configuration into an industrialised hydrosocial territory. This means that, according to the Constitutional prioritisation, roses are at the bottom of the list since water is used for a "productive activity" that does not bear direct relation to human food consumption. Here, the Constitution formally supports indigenous peasant community claims and customary rights frameworks ("uses and customs") many of which give water rights prioritisation to subsistence crops over commercial products, to guarantee family and community livelihoods (Boelens 2015).

This dictum is contested by large rose farmers on two fronts. First, they say that this prioritisation is unviable. In fact, they dispute the new rules that would literally ask for putting into practice the Water Reform - long hoped for by peasant communities, detested by powerful land/water owners. This reform is prescribed by the new Constitution but has remained merely as lip-service to the poor rural communities whose water rights have been historically dispossessed. Second, they claim that flower agribusiness requires high water rights prioritisation, because with the modernisation and technological development brought in by rose farming people can now access foods and goods that were previously unreachable.

\section{Conflicts over legitimate authority and decision-making power: the third echelon}

Irrigation water was originally in the hands of chieftains, then of hacienda owners, and later, after the Liberal Revolution, in the hands of the State. Even in the heyday of Neoliberal thinking in Ecuador, water was never considered a private good. Ecuador's current Constitution declares that irrigation water is a public good and thus it is the State's obligation to control its allocation and distribution. The Territorial Organisation, Autonomy, and Decentralisation Code (COOTAD, decreed in 2010) organises the level of government that oversees the different public services. Irrigation water lies within the provincial domain, so formally the Pisque irrigation should be primarily managed by the Pichincha Provincial Prefecture. But the story is more complicated.

There are many irrigation systems and canals that connect water flows, land, and people in the hydrosocial territory of Pisque, but, as said, two large ones stand out. One is the eponymous Pisque system, which runs roughly along the eastern portion of the basin (see Fig. 2 with main features of the area). Its rather convoluted history is akin to that of many Ecuadorian irrigation systems, i.e., first, landlords owned the system as a private asset; next, the state took over control of infrastructure and water, and then a partial and gradual transferral of management duties took place, from the State to communities (Hoogesteger 2012). This entailed large authority conflicts within changing hydrosocial governance patterns. The Pisque system is managed nowadays by a water users association.

The other main irrigation system has the Tabacundo Canal as its backbone. It runs roughly along the western part of the basin. The Municipality of Pedro Moncayo, administrator of the canal since its inception, operated, maintained, and collected fees. The hydrosocial territory saw an increasing number of users, the "modernisation" of agriculture, the presence of more prolonged dry spells, and mainly the inequity in the distribution 


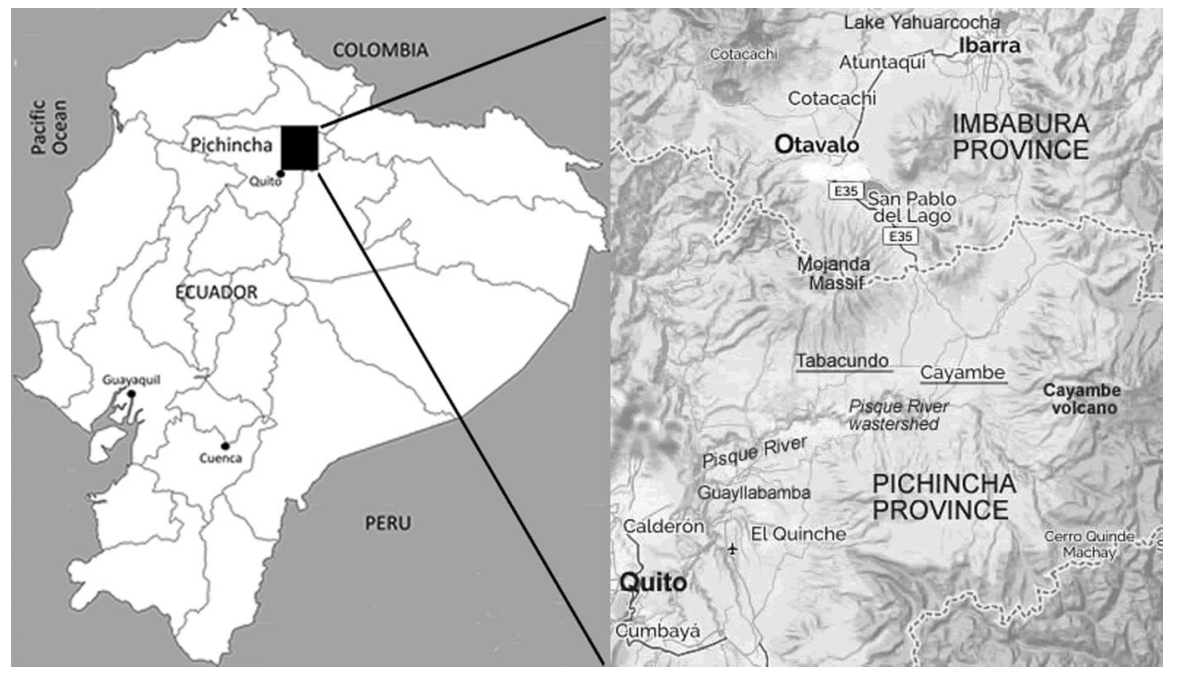

Fig. 2 Map of the main irrigation canals, municipalities, towns, and roads in the study area. The light grey oval shows the approximate location of the rose boom zone

of water (water concentration by large "white" farmers, including large rose farms). In 2006, this triggered the aforementioned mobilisation by peasant users and indigenous peoples demanding a fair distribution and a new peasant-managed administration. After a long struggle, this administration became reality and water governance is now organised by the peasant and indigenous users' organisation CODEMIA, ${ }^{3}$ which brings together communities and water users associations along the Tabacundo canal. CODEMIA's management board is made up by the presidents of each of the five sectors of the irrigation system and constitutes a second-tier, inter-community organisation (Hidalgo 2010; Hidalgo et al. 2017). This organisation operated and maintained the Tabacundo acequia, established shifts, and collected the appropriate fees from small traditional farmers and large agribusinesses.

CODEMIA did not lack difficulties: smallholders complained about entrenched favouritism towards larger users who paid more and still monopolised water. All command-area communities received water regularly, but the percentage of re-distribution has been relatively small. In any event, this organisation has been considered a cornerstone of indigenous and community struggles to (re)gain and maintain water access and decision-making rights against the interests of powerful, usually external, actors. The fact that large flower businesses have had to comply with the dictates of a peasant-led organisation bears witness to this fact. Nowadays large farmers or their representatives attend irrigation assemblies as common members.

The construction of a new canal (Canal Cayambe-Tabacundo) that will replace the Tabacundo Canal as an autonomous entity has been a remarkably cumbersome and long process that seems to be in its final phases. This will mean that CODEMIA will lose its position in

\footnotetext{
${ }^{3}$ Consorcio de Desarrollo de Manejo Integral de Agua y Ambiente para Cayambe y Pedro Moncayo (Consortium for the Development of Integrated Water and Environmental Management for Cayambe and Pedro Moncayo).
} 
the hydrosocial territory as manager of the system and will merely become a part of a new institutional arrangement led by the provincial government, as dictated by the COOTAD law. Organising this new set of relationships will constitute the next historical phase of disputed control over the hydrosocial territory, materially, politically and culturally. The water conflict among flower producers and subsistence farmers over water resources, rules, rights and authority, will unavoidably escalate again.

\section{Conflicts about discourses: the fourth echelon}

As the most abstract level, the conflicts about water, rules and authority can be related to the discourses, visions, norms, and values of the different stakeholders involved. Currently there are two mainly conflicting narratives relating to the use of the water in the Pisque hydrosocial territory: first, water should be available to the indigenous communities for food sovereignty, and second, water should be used to its highest economic potential, i.e. flower businesses, which will also create jobs for indigenous community members. The "flowers" discourse strongly emphasises the progress and modernisation roses have brought into the regions where floriculture has flourished, while the "food" discourse intensely questions its inception on grounds of pollution, food and water security, and cultural erosion (Mena Vásconez et al. 2016).

The material and discursive contradictions of 'local food' versus 'alien flowers' would be an upgrading of previous struggles between local peasant communities and varied external actors in the hydrosocial territory. Perhaps at the beginning, divisions and power relationships were indeed strongly dichotomous, both materially and discursively: Kayambi versus Inca, indigenous communities versus Spaniards and later white-mestizo elites and their haciendas versus huasipungos and indigenous peasants. More recently this has found form in indigenous communities versus large capitalist flower farms. But as far back as the early history of the region, some indigenous communities allied themselves with the invaders, creating a sort of midway stakeholder that saw the invasion as a way to improve existing inequalities. Dynamic negotiation and hybridisation of positions and powers has coloured Pisque's hydrosocial territory historically. With the advent of cows, the dichotomy became more blatantly insufficient since at least some communities took in the new commodity and, as said previously, even became quite successful.

Flowers show some similarities to the previous dairy-related production model, yet at least one sharp difference emerges: flowers are non-edible. Even if cows could be deemed a foreign element, milk, cheese, and other dairy foodstuffs had been part of the diet for decades and even some local races of cows and varieties of cheese had been developed, as well as local grasses adapted as fodder. On the other hand, discussions about food sovereignty and security do not seem to have had a high priority in the social arena at the time of the dairy boom. Flowers, a non-comestible, highly demanding commodity, but with the advantage of bringing jobs and a general sense of prosperity, impelled at least some of the community members to pursue the dream of having something that had never been destined for them.

Thus, the dichotomous discursive struggle of, on the one hand, modernity, prosperity, cultural integration and universalization of rules and governance (typical of large farmers and, to some extent, deployed by local authorities), and, on the other hand, that of food security and sovereignty coupled with self-determination and notions of cultural independence (exposed by local leaders and the community in general), became an increasingly entangled scenario of values. Some community members were tempted to grow roses in 
their small plots, albeit keeping at least some area for traditional agriculture, finding that it was not only possible but also desirable and even multipliable (Vasco et al. 2017).

A new chapter in this ultimately value-based material and discursive struggle is beginning. After having been unable (or unwilling) to establish associations among the smallholders due mainly to a lack of confidence in the leaders, it seems that finally small Pisque (flower) farmers are increasingly embracing a "strength-in-numbers" approach. An upscaling of their isolated small businesses into multi-member associative entities could mean a huge advantage in economic and political terms ${ }^{4}$ - that is, for those smallholders who are able to join the flower game within this novel hydrosocial territory.

\section{Conclusions}

In this paper we have examined the Pisque basin's changing configuration of the hydrosocial territory focussing on water flows, rights, and governance forms as constituted by historically shaped power relationships. We have scrutinised water conflicts as encompassing four connected echelons: first, over access to resources; second, over the substance and meaning of the norms and rules defining water allocation; third, over legitimate authority to manage the irrigation systems and define rules and norms; and fourth, over discourses. The latter, as regimes of representation, impose or defend particular water hierarchies and policies, legitimising the patterning of these resource distributions, rules, and authorities in hydrosocial territories "convenient" for those who (think to) benefit from that particular territorial configuration.

Currently, in Ecuador as in many other places, it is increasingly the water resource that trigger mobilisation and shifting contradictions, continuously reconfiguring the economicpolitical relationships and socionatural composition of the hydrosocial territory. The history of the Pisque watershed-focused on the conflicts related to the access to and control of irrigation water-is a stage where, for centuries, local actors have suffered, struggled, and mobilised against the encroachment of powerful external actors.

The current boom of large export flower businesses - and the even more recent boom of small local flower producers - constitutes the latest chapter in this struggle. The seemingly abundant Andean water has been the cornerstone of a series of conflicts at several levels that demonstrate that, even if the ecological sponges of the highland páramos are able to collect and distribute good water to the lowlands, a scarcity has been constructed that is a product of a profoundly skewed distribution of the resource rather than an abstract "climate change" issue. This inequality does not relate only to water, which could be understood as the most noticeable element, but also to land, credit, supplies, marketing know-how, and connections.

A cyclic phenomenon is recognisable in the various episodes summarised in this article. In general, without denying internal frictions and large inequities, it has always been a tale of local people seeing their rights to water and land encroached upon by powerful outsiders. There have been always resistance and insurgence, and some rights have been reclaimed, even if the situation of the indigenous population of the Pisque has not really structurally improved. Currently it is obvious, for example, that local people are not

\footnotetext{
${ }^{4}$ Milk farmers had success in establishing dairy associations, but it was done based on edible things that were consumed locally and regionally.
} 
a serf-like population under the orders of the higher classes anymore but have reclaimed their dignity. Yet profound inequalities linger and continue to develop.

The cycle is clearer in more recent times. With dairy farms, some of the communities were able to successfully establish powerful associations that competed well with the remaining haciendas still in hands of white elites. The advent of roses in large farms, with international funding and deeply commoditised production relations, led to the idea that this was an endeavour totally outside the capabilities of small farmers, and so it was for some three decades when they only participated as low-level waged workers who could only dream of becoming floriculturalists.

But the new boom of successful small locally managed export-quality rose greenhouses has proved the initial assumption wrong, at least partially or momentarily. Thus, a traditional dichotomy has become a more complex mesh of conflicts where battles over resources, rules, authorities, and discourses structure a situation that, having parallels to the dairy arena of the past, presents a rather unpredictable outcome in terms of justice, equity, and self-determination. The new trend has developed of association and cooperation between stakeholders who were initially wary of forming partnerships. This trend could mean a leap into more competitiveness and progress, but at the cost of impinging even deeper on long-cherished notions such as autonomy, food and water security and sovereignty.

Open Access This article is licensed under a Creative Commons Attribution 4.0 International License, which permits use, sharing, adaptation, distribution and reproduction in any medium or format, as long as you give appropriate credit to the original author(s) and the source, provide a link to the Creative Commons licence, and indicate if changes were made. The images or other third party material in this article are included in the article's Creative Commons licence, unless indicated otherwise in a credit line to the material. If material is not included in the article's Creative Commons licence and your intended use is not permitted by statutory regulation or exceeds the permitted use, you will need to obtain permission directly from the copyright holder. To view a copy of this licence, visit http://creativecommons.org/licenses/by/4.0/.

\section{References}

Acción Ecológica (2000) Las Flores del Mal: Las floricultoras y su crecimiento acelerado'. Alerta 88

Agnew J (1994) The territorial trap: the geographical assumptions of international relations theory. Rev Int Polit Econ 1(1):53-80

Albornoz C (2014) La Revolución que no Redimió al Indio Ecuatoriano. Ciencias Sociales 35:259-280

Aspiazu R (2014) El Quichua, lengua para evangelizar. El Comercio de Quito, November 15 2014. https:// especiales.elcomercio.com/planeta-ideas/ideas/16-de-noviembre-2014/quichua-lengua-para-evangeliza $\mathrm{r}$

Athens JS (1980) El proceso evolutivo de las sociedades complejas y la ocupación del período tardío Cara en los Andes septentrionales del Ecuador. IOA Pendoneros, Otavalo

Bain C, Selfa T (2013) Framing and reframing the environmental risks and economic benefits of ethanol production in Iowa. Agric Hum Values 30(3):351-364

Becker M, Tutillo S (2009) Historia Agraria y Social de Cayambe. FLACSO/Abya-Yala, Quito

Benford RD, Snow DA (2000) Framing processes and social movements: an overview and assessment'. Ann Rev Sociol 26(1):611-639

Boelens R (2009) The politics of disciplining water rights. Develop Change 40(2):307-331

Boelens R (2014) Cultural politics and the hydrosocial cycle: water, power and identity in the Andean Highlands. Geoforum 57:234-247

Boelens R (2015) Water, power and identity: the cultural politics of water in the Andes. Routledge, London

Boelens R, Hoogesteger J, Baud M (2015) Water reform governmentality in Ecuador: Neoliberalism, centralization, and the restraining of polycentric authority and community rule-making. Geoforum 64:281-291 
Boelens R, Hoogesteger J, Rodríguez-de-Francisco JC (2014) Commoditizing water territories: the clash between Andean water rights cultures and payment for environmental services policies. Capital Nat Social 25(3):84-102

Boelens R, Hoogesteger J, Swyngedouw E, Vos J, Wester P (2016) Hydrosocial territories: a political ecology perspective. Water Int 4(1):2

Boelens R, Perreault T, Vos J (eds) (2018) Water justice. Cambridge University Press, Cambridge

Borg Rasmussen M, Lund C (2018) Reconfiguring frontier spaces: the territorialisation of resource control. World Dev 101:388-399

Borja R (2012) Enciclopedia de la Política. FCE, México

Brassel F, Herrera S, Laforge M (eds) (2008) ¿Reforma Agraria en el Ecuador? Viejos temas, nuevos argumentos. SIPAE, Quito

Bray T, Echeverría, J (2014) Al final del Imperio: El sitio arqueológico Inca-Caranqui en la Sierra Septentrional del Ecuador. Antropología Cuadernos de Investigación, 13: enero-junio:127-150

Breilh J (2007) Nuevo Modelo de Acumulación y Agroindustria: Las Implicaciones Ecológicas y Epidemiológicas de la Floricultura en Ecuador. Ciência e Saude Colectiva, Rio de Janeiro

Castillo C (2006) La acequia Tabacundo. Foro de los Recursos Hídricos, Quito

Costales A, Costales D (1987) Huambracuna La epopeya de Yahuarcocha. Abya-Yala and IEAG, Quito

de Vos H, Boelens R, Bustamante R (2006) Formal law and local water control in the Andean region: a fiercely contested field. Int J Water Resour Dev 22(1):37-48

Duarte-Abadía B, Boelens R, Roa-Avendaño T (2015) Hydropower, encroachment and the repatterning of hydrosocial territory: the case of Hidrosogamoso in Colombia. Hum Org 74(3):243-254

Elden S (2010) Land, terrain, territory. Prog Hum Geogr 34(6):799-817

Foucault M (1995) Discipline and punish. The birth of the prison. Vintage Books, New York

French A (2018) Webs and flows: socionatural networks and the matter of nature at Peru's Lake Parón. Ann Am Assoc Geogr. https://doi.org/10.1080/24694452.2018.1484682

García M, Parra D, Mena-Vásconez P (2014) El País de la Biodiversidad: Ecuador. Ministerio del Ambiente and Ecofondo, Quito

Gaybor G (2011) Acumulación capitalista en el campo y despojo del agua. Foro Nacional de los Recursos Hídricos, Quito

Guerra ME (2012) Cayambe: entre la agroempresa y la biodiversidad. FLACSO, Quito

Harvey D (2015) A brief history of neoliberalism. OUP, Cambridge

Hayek FA (1944) The road to serfdom. George Routledge, London

Hidalgo JP (2010) Dinámica de acumulación de derechos de agua y conflictos Estudio de caso de la Acequia Tabacundo, Ecuador. Wageningen University, Wageninge

Hidalgo JP (2015) La floricultura y la exclusión de acceso al agua de riego: El caso de la acequia Tabacundo en la Sierra ecuatoriana'. In: Budds J, Roa-García C (eds) Justicia Hídrica. PUCP, Lima

Hidalgo JP, Boelens R, Vos J (2017) De-colonizing water. Dispossession, water insecurity, and Indigenous claims for resources, authority, and territory. Water Hist 9(1):67-85

Hommes L, Boelens R (2017) Urbanizing rural waters: rural-urban water transfers and the reconfiguration of hydrosocial territories in Lima. Polit Geogr 57:71-80

Hommes L, Boelens R (2018) From natural flow to 'working river': hydropower development, modernity and socio-territorial transformations in Lima's Rímac watershed. J Hist Geogr 62:85-95

Hommes L, Boelens R, Maat H (2016) Contested hydro-social territories and disputed water governance: struggles and competing claims over the Ilisu Dam development in south-eastern Turkey. Geoforum 71:9-20

Hoogesteger J (2012) Trans-forming social capital around water: water user organizations, water rights, and non-governmental organizations in Cangahua, the Ecuadorian Andes. Soc Nat Resour 26(1):60-74

Hoogesteger J, Boelens R, Baud M (2016) Territorial pluralism: water users`́ multi-scalar struggles against state ordering in Ecuador's highlands. Water Int 41(1):91-106

Hoogesteger J, Verzijl A (2015) Grassroots scalar politics: insights from peasant water struggles in the Ecuadorian and Peruvian Andes. Geoforum 62:13-23

Hulshof M, Vos J (2016) Diverging realities: how frames, values and water management are interwoven in the Albufera de Valencia wetland, Spain. Water Int 41(1):107-124

Icaza I (1950) Huasipungo. El Perro y la Rana Ediciones, Caracas

Jackson S (2018) Water and Indigenous rights: mechanisms and pathways of recognition, representation, and redistribution. WIREs Water. https://doi.org/10.1002/wat2.1314

Jordán F (2003) Reforma Agraria en el Ecuador. In: Vargas Vega JD (ed) Proceso agrario en Bolivia y América Latina. Plural Editores, La Paz

Korovkin K, San Miguel-Valderrama O (2007) Labour standards, global markets and non-state initiatives: Colombia's and Ecuador's flower industries in comparative perspective. Third World Q 28(1):117-135 
Larraín H (1980) Demografía y Asentamientos Indígenas en la Sierra Norte del Ecuador en el siglo XVI. IOA, Pendoneros, Otavalo

Linton J, Budds J (2014) The hydrosocial cycle: defining and mobilizing a relational-dialectical approach to water. Geoforum 57:170-180

Manosalvas R (2016) La paradoja en las políticas públicas del agua sobre los territorios hídricos en un gobierno antineoliberal. Las aguas no se asientan en el Ecuador. In: Duarte-Abadía B, Yacoub C, Hoogesteger J (eds) Gobernanza del Agua. Abya-Yala, Quito, pp 34-40

Marks D (2019) Assembling the 2011 Thailand floods: protecting farmers and inundating high-value industrial estates in a fragmented hydro-social territory. Polit Geogr 68:66-76

McGarry J, O’Leary B (2014) Territorial pluralism: taxonomizing its forms. Flaws and Virtues University of British Columbia Press, Vancouver

Meehan K (2013) Disciplining de facto development: water theft and hydrosocial order in Tijuana. Environ Plan D 31:319-336

Meisel JE, Woodward CL (2005) Andean Orchid conservation and the role of private lands: a case study from Ecuador. Selbyana 26(1-2):49-57

Mena-Vásconez P, Boelens R, Vos J (2016) Food or flowers? Contested transformations of community food security and water use priorities under new legal and market regimes in Ecuador's highlands. J Rural Stud 44:227-238

Mena-Vásconez P, Vincent L, Vos J, Boelens B (2017) Fighting over water values: diverse framings of flower and food production with communal irrigation in the Ecuadorian Andes. Water Int 42(4):443-461

Mena-Vásconez P, Vos J, van Ommen P, Boelens R (2019) Flores, acaparamiento del agua y Responsabilidad Empresarial Social: certificación de la producción de rosas y reclamos por la justicia ambiental en el Ecuador'. Cuadernos de Geografía 101

Mena-Vásconez P, Castillo A, Flores S, Hofstede R, Josse C, Lasso S, Medina G, Ochoa N, Ortiz D (eds) (2011) Páramo, paisaje estudiado, habitado, manejado e institucionalizado. Abya-Yala, Quito

Meyers A (1998) Die Inka in Ekuador. Untersuchungen anhand ihrer materieller Hinterlassenshchaft, Estudios Americanistas de Bonn

Murra J (1946) The Historic Tribes of Ecuador, Volumen 2 of Handbook of South American Indians. Smithsonian Institution Bureau of American Ethnology, Washington DC

Ochoa M (2013) Plan Integral de Gestión del Riego en la Zona de Influencia de la Acequia Tabacundo. Master's Thesis. Universidad Politécnica Salesiana, Quito

Parramond EP (2016) Adjudicating hydrosocial territory in New Mexico. Water Int 41(1):173-188

Perreault T (2014) What kind of governance for what kind of equity? Towards a theorization of justice in water governance. Water Int 39(2):233-245

Polanyi K (1944) The great transformation: the political and economic origins of our time. Farrar \& Rinehart, New York

Ramón R (1987) La resistencia indígena. CAAP, Quito

Roa-García C (2014) Equity, efficiency and sustainability in water allocation in the Andes: trade-offs in a full world. Water Altern 7(2):298-319

Rogers S, Crow-Miller B (2017) The politics of water: a review of hydro political frameworks and their application in China. WIREs Water. https://doi.org/10.1002/wat2.1239

Roth D, Boelens R, Zwarteveen M (2015) Property, legal pluralism, and water rights: the critical analysis of water governance and the politics of recognizing "local" rights. J Legal Plural Unoff Law 47(3):456-475

Salomon F (1980) Los señores étnicos de Quito en la época de los Incas. IOA Pendoneros, Otavalo

Sanchis-Ibor C, Boelens R, García-Mollá M (2017) Collective irrigation reloaded. Re-collection and remoralization of water management after privatization in Spain. Geoforum 87:38-47

Sawers L (2005) Non-traditional or new traditional exports: Ecuador's Flower Boom. Lat Am Res Rev 40(3):40-67

Scott JC (1985) Weapons of the weak. Everyday forms of peasant resistance. Yale University Press, New Haven

Soper R (2013) Reclaiming development: indigenous community organizations and the flower export industry in the Ecuadorian Highlands'. In: Becker M (ed) Indigenous and Afro-Ecuadorians facing the twenty-first century. Cambridge Scholars Publishing, Newcastle, pp 128-149

Stoltenborg D, Boelens R (2016) Disputes over land and water rights in gold mining: the case of Cerro de San Pedro, Mexico. Water Int 41(3):447-467

Swyngedouw E (2009) The political economy and political ecology of the hydrosocial cycle. J Contemp Water Res Educ 142:56-60 
Swyngedouw E, Boelens R (2018) “...And Not a Single Injustice Remains”: hydro-territorial colonization and techno-political transformations in Spain. In: Boelens R, Perreault T, Vos J (eds) Water justice. Cambridge University Press, Cambridge, pp 115-133

Terán R (1994) La Historia Económica y Social sobre la Época Colonial Ecuatoriana. Proces Rev Ecuat Hist 5:29-52

UN Comtrade, Flower export. https://comtrade.un.org/data/. Accessed 1 Nov 2015

Vasco C, Tamayo G, Griess V (2017) The drivers of market integration among indigenous peoples: evidence from the Ecuadorian Amazon. Soc Nat Resour 30(10):1212-1228

Vázquez-Figueroa A (2012) Codicia. Debolsillo, Madrid

Vos J, Hinojosa L (2016) Virtual water trade and the contestation of hydrosocial territories. Water Int 41(1):37-53

Wilson NJ, Inkster J (2018) Respecting water: Indigenous water governance, ontologies, and the politics of kinship on the ground. Environ Plan E. https://doi.org/10.1177/2514848618789378

Yacoub C, Duarte-Abadía B, Boelens R (2015) Agua y Ecología Política. El extractivismo en la agroexportación, la minería y las hidroeléctricas en Latino América. Abya-Yala, Quito

Zapatta Á, Mena-Vásconez P (2013) Acumulación de agua y floricultura en un mosaico de territorios de riego: el caso Pisque, Ecuador. In: Arroyo A, Boelens R (eds) Aguas Robadas Abya-Yala, Quito, pp $167-184$

Zwarteveen M, Boelens R (2014) Defining, researching and struggling for water justice: some conceptual building blocks for research and action. Water Int 39(2):143-158

Publisher's Note Springer Nature remains neutral with regard to jurisdictional claims in published maps and institutional affiliations.

Patricio Mena-Vásconez was born in Quito and studied biology (CUNY) and journalism (Cardiff) before entering the field of political ecology. After working as a botanist at Pontificia Universidad Católica del Ecuador and as an ecologist and environmental planner for the NGO EcoCiencia, mainly in the high Andean ecosystems known as páramos, he decided to pursue a PhD degree in Wageningen, where he recently finished his dissertation on water governance.

Rutgerd Boelens is Professor 'Political Ecology of Water in Latin America' holding a part-time special chair with CEDLA and the University of Amsterdam (Social and Behavioural Sciences FMG/GPIO and Humanities). He also works as Professor 'Water Governance and Social Justice' at Wageningen University (Environmental Sciences Group, Water Resources Management), and is Visiting Professor at the Catholic University of Peru and the Central University of Ecuador. He directs the international Justicia Hídrica/Water Justice alliance, engaged with comparative research and training on water accumulation, conflict and civil society action.

Jeroen Vos is Assistant Professor at the department of Water Resources Management of Wageningen University, the Netherlands. As a water policy advisor, he worked almost a decade in Peru and Bolivia. His current research interests are the dynamics and discourses of water use by agribusinesses in Latin America. He has published on different aspects of water governance struggles and was co-editor of the "Water Justice" book, published by Cambridge University Press in 2018. 